\title{
DIGITAL YUAN - CURRENCY OR POLICY TOOL?
}

\author{
MARTIN SAMEK, MARTIN VLASTA
}

Abstract: $\quad$ Digital Yuan - Currency or Policy Tool?

Central bank digital currencies (CBDCs) are Bitcoin-inspired currencies that combine aspects of virtual currencies with FIAT money. Many central banks and countries around the world are thinking about or planning to introduce some form of CBDC. Among them, China is leading the way, being the first country to issue their CBDC (Digital RMB) into circulation, even if it is yet a pilot program only. This article focuses not only on the Digital RMB and its legal implementation but also on the political, historical, and economic circumstances of its birth, which, when talking about anything related to China, is often crucial to understanding the phenomenon more than the legal provisions themselves. The aim is to deepen the understanding of legal policies in China and open a discussion about the Digital RMB.

Keywords: digital currency; CBDC; China; Yuan

Klíčová slova: digitální měna; CBDC; Čína; jüan

DOI: $10.14712 / 23366478.2021 .28$

\section{INTRODUCTION}

Ever since the advent of civilization, humans' understanding of the concept of value kept evolving into a more abstract and less tangible form. We have progressed from a pouch of silver coins that based its value on the metal itself to a cashless world where transactions are settled over vast distances, in real-time, at near-instant speeds, all thanks to a multi-tiered digital infrastructure, part private, part public. The distance between the owner and the object of their ownership, i.e., value, is increasing, and physical substance is disappearing.

From a hand-to-hand exchange of physical goods, transactions have become only communications between the market operators tallying their net settlements. An actual authentic digital currency would be the next logical evolutionary step. We are witnessing a new phenomenon that possibly may change everyone, everywhere, and everything. And although the vast majority of the world's central banks have already started to conceptualize and research the potential for CBDCs, ${ }^{1}$ as of 2020 , a significant portion

1 CBDC is an abbreviation for Central Bank Digital Currency a digitalized version of standard currencies like the digital RMB or digital Euro. This term will be more thoroughly explored in this paper. 
of them were building proofs-of-concept, and 10\% were deploying pilot projects, according to research conducted by the Bank of International Settlements (BIS), ${ }^{2}$ China is the first country to employ real and impactful steps towards a functioning digital currency. In this article, the authors analyze the Digital Yuan as a new legal, economic, and cultural phenomenon, the process of its implementation, its goals, uses, and impact on society. In this paper, we will discuss the digital Yuan and the legal, political, economic, and even historical and sociological circumstances that lead to its creation and will be key to understanding its future.

\section{FIRST STEPS TOWARDS CHINA'S DIGITAL CURRENCY}

In 2020, China made several meaningful steps towards implementing the so-called "Digital Yuan", also called DCEP (Digital Currency Electronic Payment). ${ }^{3}$

A pivotal moment was The State Council's decision on 2 August giving the Ministry of Commerce the go-ahead with the Master Plan. ${ }^{4}$ The details of the Master Plan revealed the scope of the undertaking and some of the technical details. These are the first actual steps taken by a country's government to deploy a digital currency on such a vast scale, making previous government attempts, such as Senegal's and Tunisia's eCFA, Venezuela's petro, and Marshall Islands' Sovereign pale in comparison. ${ }^{5}$

According to the original Master Plan, the digital RMB was to be deployed in a handful of municipalities of Shenzhen, Suzhou, Xiong'an, Chengdu, and also during the Winter Olympics in Beijing in February 2022. ${ }^{6}$ Those cities are known technology hubs and often compared to Silicon Valley in California. ${ }^{7}$ In August 2020, even more economically significant municipalities were ordered to join in on the pilot project by the Ministry of Industry and Commerce. ${ }^{8}$ Among Beijing, Shanghai, Tianjin, and Hebei, to name a few examples, many other cities are to carry out the same pilot project. ${ }^{9}$

2 CODRUTA, B. - HOLDEN, H. - WADSWORTH, A. Impending arrival - a sequel to the survey on central bank digital currency. BIS Papers. 2020, Vol. 107, p. 3.

3 Alternatively, also referred to as CBDC (Central Bank Digital Currency).

4 Decision of State Council State Letter. 2020, No. 111. In: Peking University Law School [online]. 2.8.2020 [cit. 2021-03-10]. Available at: https://www.pkulaw.com/chl/02789cd98d52bafbbdfb.html.

5 O'NEIL, S. State-Issued Digital Currencies: the Countries Which Adopted, Rejected or Researched the Concept. In: Cointelegraph [online]. [cit. 2021-03-24]. Available at: https://cointelegraph.com/news/state -issued-digital-currencies-the-countries-which-adopted-rejected-or-researched-the-concept.

6 Decision of State Council State Letter.

7 See e.g., Four major cities in China named among top 20 technology innovation hubs, finds KPMG's annual survey. In: Hong Kong Monetary Autority: Press Releases [online]. 16.3.2020 [cit. 2021-03-10]. Available at: https://home.kpmg/cn/en/home/news-media/press-releases/2020/03/four-major-cities-in-china -named-among-top-20-technology-innovation-hubs.html.

8 Notice of the Ministry of Commerce on Issuing the Overall Plan for Comprehensively Deepening the Pilot Program for the Innovation and Development of Trade in Services. Commercial Service Trade Development [online]. 2020, No. 165, 14.8.2020. [cit. 2021-03-10]. Available at: http://www.mofcom.gov.cn /article/b/xxfb/202008/20200802992306.shtml.

9 CHENG, J. China Rolls Out Pilot Test of Digital Currency. Wall Street Journal [online]. 20.4.2020 [cit. 2021-03-10]. Available at: https://www.wsj.com/articles/china-rolls-out-pilot-test-of-digital-currency $-11587385339 \#$. 
The Chinese government has been rather tight-lipped regarding the technical nature of data handling and storage of sensitive data. However, it was disclosed to the public that the Digital Yuan will employ a centralized (account-based) model as opposed to a decentralized - consensus-based model - while at the same time allowing for limited offline transactions. ${ }^{10}$ The Chinese government has opted for a two-tiered system of administration, where the existing banks that operate the robust financial infrastructure will become devolved units subordinate to the People's Bank of China (PBOC), which will administer the system from the top. ${ }^{11}$

At this point, however, the term "pilot project" is quite misleading, at least by European standards, because it implies small scale or experimental use only. Such assumption could not be farther from the truth. To get involved, all one needs is to happen to live in extensive urban areas along the mainland coast and download a free app on their smartphone. So far, China's Big Four ${ }^{12}$ have developed the interface for the new currency within their platform app. More banks are on the way to follow suit.

To further drive the attractiveness of the new form of currency, in January of 2021, in a big PR move financed by Shenzhen's Futian District that encompasses most of the city center, 20 million digital Yuan was randomly distributed through a digital lottery in digital Red Envelopes among 100000 eligible citizens, who have downloaded the app. One could wind up receiving 200 Yuan out of thin air. ${ }^{13}$ The money, however, can only be spent through the app sanctioned by the Government. In order to complete the payment, the retailers are also required to download the app and sign up for an account. This subsequently drives the adoption rate on the supply side of the market.

The Master Plan resulted from long-held discussions that started back in 2013 when cryptocurrencies were introduced to China, their potency recognized, their status immediately regulated, and shortly after that banned. This is not the first time a government reacted when it felt like their monetary sovereignty was threatened; Ecuador went through a similar regulatory pattern in 2014. ${ }^{14}$

On 3 December 2013, the People's Bank of China (PBOC) issued a notice of precaution against Bitcoins, essentially prohibiting Bitcoin operations by banks and financial institutions in China amid concerns of circumventing the existing strict financial and

10 See Annex 2 art. 3 par. 3 of Notice of the People's Bank of China on Public Consultation on the Law of the People's Republic of China on the People's Bank of China (Revised Draft). In: The People's Bank of China [online]. 23.10.2020 [cit. 2021-03-27]. Available at: http://www.pbc.gov.cn/goutongjiaoliu /113456/113469/4115077/index.html.

11 YIFEI, F. Thoughts on CBDC Operations in China. In: Yicai Global [online]. 8.4.2020 [cit. 2021-05-09]. Available at: https://www.yicaiglobal.com/news/thoughts-on-cbdc-operations-in-china.

12 China Construction Bank, Bank of China, Industrial and Commercial Bank of China, Agricultural Bank of China.

13 Shenzhen Futian District Launches Digital RMB Red Envelope Pilot. In: Shenzhen People's Bank of China [online]. 4.1.2021 [cit. 2021-03-30]. Available at: http://shenzhen.pbc.gov.cn/shenzhen/122807/4157147 /index.html.

14 KHAOSAN, V. Ecuador Bans Bitcoin in Favor of Own National Cryptocurrency. In: Cointelegraph [online]. [cit. 2021-03-24]. Available at: https://www.ccn.com/ecuador-bans-bitcoin-favor-own-national -cryptocurrency/. 
capital markets regulations. ${ }^{15}$ In 2017, in the joint statement of PBOC and six other state regulators, the so-called initial coin offerings (ICO) ${ }^{16}$ were banned across China entirely. ${ }^{17}$ The third came within a month from the previous one, when all Beijing-based cryptocurrency exchanges were ordered to halt new registrations and prepare exit plans to leave the market within a very short, strict period. ${ }^{18}$

Many ministries, departments, and state agencies were involved in the conversation. The leading role of a moderator, as well as the department that brought the pilot plan forward and assumed the leadership and responsibility for it, was the Ministry of Industry and Commerce. ${ }^{19}$ Another key player was the People's Bank of China, which focused on legislation and proposed a draft of a new banking law encompassing the new digital currency. ${ }^{20}$

\section{THE PROSPECTS OF THE DIGITAL YUAN}

What are China's intentions with the Digital Yuan? To understand this question and understand the underlying regulation of, not only the Digital Yuan, but also the regulation of cryptocurrencies as well, the motive needs to be established.

Some motivations can be cited from the recitals of the new Banking Act, some that can be cited from the decision of the State Council, and some can be referred from public speeches or political proclamations, and details of the 14th Five-Year Plan, ${ }^{21}$ all establishing their legitimacy in the Chinese Constitution.

We think those at least remotely familiar with the Chinese political environment will agree that the modern Chinese legal tradition and definition of Chinese lawgiving ought

15 MULlanY, G. China Restricts Banks' Use of Bitcoin. The New York Times [online]. 5.12.2013 [cit. 2021-03-10]. Available at: https://www.nytimes.com/2013/12/06/business/international/china-bars -banks-from-using-bitcoin.html.

16 An Initial Coin Offering is a way to get initial funding for cryptocurrency development and release in exchange for the cryptocurrency coins-to-be. It can be compared to more and more popular crowdfunding. With laws preventing ICOs of cryptocurrencies (or "virtual currencies", as the announcement mentioned calls them), it can be very hard for many smaller cryptocurrency projects come into life. The announcement classifies these ICOs as a form of public financing that is illegal.

17 Announcement of People's Bank of China, Cyberspace Administration of China, State Administration for Industry and Commerce, China Banking Regulatory Commission, China Securities Regulatory Commission and China Insurance Regulatory Commission on Preventing Financial Risks from Initial Coin Offerings. In: The People's Bank of China [online]. 4.9.2017 [cit. 2021-03-12]. Available at: http://www .pbc.gov.cn/goutongjiaoliu/113456/113469/3374222/index.html.

18 China moves to shut down cryptocurrency exchanges. China Daily [online]. 19.9.2017 [cit. 2021-03-12]. Available at: http://www.chinadaily.com.cn/a/201709/19/WS59c1b1a2a3103e4e43a07ceb.html.

19 Notice of the Ministry of Commerce on Issuing the Overall Plan for Comprehensively Deepening the Pilot Program for the Innovation and Development of Trade in Services. In: Peking University Law School [online] 12.8.2020 [cit. 2021-03-30]. Available at: https://www.pkulaw.com/chl/c87179125774b $97 \mathrm{cbdfb}$ .html.

20 Notice of the People's Bank of China on Public Consultation on the "Law of the People's Republic of China on the People's Bank of China”. In: Peking University Law School [online]. 23.10.2020 [cit. 2021-03-30]. Available at: http://www.pbc.gov.cn/goutongjiaoliu/113456/113469/4115077/index.html.

21 The Fourteenth Five-Year Plan for the National Economic and Social Development of the People's Republic of China and the Outline of Long-term Goals for 2035. In: Peking University Law School [online]. 11.3.2021 [cit. 2021-03-27]. Available at: https://www.pkulaw.com/chl/dad03bd96074290cbdfb.html ?keyword=宏观审慎政策指引. 
to start with the following terms and must be present in any legislation or policy, should it have any chance to pass through the current Standing Committee of the National People's Congress:22

- Stability

- Reform

- The rule of law

- Strengthening

- Xi Jinping's Thought on Socialism with Chinese Characteristics for a New Era

Considering the specific aims the Digital Yuan is meant to achieve; the following is openly disclosed in legislation and recitals (translated, structured, and paraphrased for briefness's sake): ${ }^{23}$

"Strengthening the means of the People's Bank for performing duties:

- comprehensive statistics of the financial industry

- macro-prudential management and policy toolboxes such as stress testing

- penetrating supervision of

- systemically important financial institutions

- financial holding companies

- important financial infrastructure

- increase penalties for financial violations

Improving the stability of the currency

- maintain economic and social security and stability

- tackle poverty alleviation financial services

- systemic financial risk prevention

- counter-cyclical adjustment capital buffers

- risk reserves for financial institutions

- reforms on the financial supply side

A policy to further deploy principles of marketization and liberalization

- continue to strengthen private small and micro enterprises

- continue to adhere to the principle of the People's Bank of China not directly subscribing or underwriting treasury bonds and other government bonds, and not providing loans to local governments"

The above-mentioned bullet points represent the gist of the extensive language used in the documentation that accompanies the legislation.

22 National People's Congress (NPC) and Standing Committee of the National People's Congress (NPCSC) are the main legislative bodies of People's Republic of China.

23 See Notice of the People's Bank of China on Public Consultation on the Law of the People's Republic of China on the People's Bank of China (Revised Draft). 
The authors of this text think that another set of goals can be interpreted from the available evidence. ${ }^{24}$ One that is based more on the overall context of the Chinese nation, current problems, and therefore the solutions that the Digital Yuan promises to bring to the table. They will be further explored in the following paragraphs:

1. Ensuring the stability of the global market-based liberal system that is fundamentally prone to cyclic systemic risks through macroprudential policies while promoting marketization and liberalization principles.

2. Achieving monetary sovereignty for an export-heavy country, resistance to external monetary policy actions executed by foreign governments $(\mathrm{QE}$, interest rate changes, effects of uncontrollable inflation).

3. Being a "weapon" in the ongoing US-China trade war - (Digital) RMB as a contender for new world reserve currency.

4. Expanding and further developing foreign horizons, i.e., Asian Co-Prosperity Sphere, African markets, EU+ markets, The New Silk Road initiatives, and so on.

5. Developing new analytical tools to monitor and improve policymaking, both internal (predicting market forces) and external (monitoring the in and out flows of capital, financial roaming).

6. Eradicating corruption, crime, terrorism, money laundering, disruptive information, delivering new tools for government to enforce laws.

7. Limiting the influence of platforms, such as Alipay and WeChat Pay, which are controlled by fintech companies.

8. Protecting against the threat of other currency alternatives (foreign currencies, private currencies, neutral cryptocurrencies), either legally or through market forces.

9. Bridging the gap between the two parts of China, urban and rural, eradicating poverty and providing all Chinese citizens with easy to use, efficient, convenient, reliable method of exchange of money, thereby bringing the fruits of the civilization to every single Chinese citizen.

10. Improving the capacity for government to ensure more efficient administration of taxation.

\section{STABILITY THROUGH ANTI-CYCLIC MACROPRUDENTIAL POLICIES}

Stability is the utmost priority to Chinese society and culture. The history of China is divided between times of peace and unity guaranteed by the leading dynasty whose leadership possesses the Mandate of the Heaven and times of warring states and internal struggles. The possessor of the Mandate of the Heaven has been for many years now the Chinese Communist Party and through the party the Chinese government. ${ }^{25}$

24 E.g., id.; and The Fourteenth Five-Year Plan for the National Economic and Social Development of the People's Republic of China and the Outline of Long-term Goals for 2035.

25 See e.g., TOMÁŠEK, M. Právní systémy Dálného východu. II. Praha: Karolinum, 2019, p. 342. 
The Chinese government is trying to maintain the stable growth of a nation totaling up to 1.4 billion people. In the early stages of the modern Chinese nation, capitalist market economies used to be deemed too disruptive of a method to bring the nation wealth; therefore, an economy featuring central planning was chosen. This steadfast opinion became more nuanced throughout history. Due to the harsh lessons learned, in the end, Chinese pragmatism recognized the utility of markets and adapted their system accordingly. ${ }^{26}$ This reformation is captured in a Chinese proverb often attributed to Deng Xiaoping: "It doesn't matter whether a cat is black or white, as long as it catches mice." Currently, this is manifested in "high-tech macroprudential policies with Chinese characteristics" spoken of in the 14th Five-Year Plan, approved by the National People's Representative Meeting recently on 11 March 2021.27 And as for the digital Yuan, that is merely a new monetary policy enforcement tool within this new policy framework.

"The art of reform is: when there is a window, we must push forward decisively, and when there is no window, we must wait for a while and create conditions. China's economic forecasts a balance between reform, development, and stability. The entire international economy is recovering from the crisis, and the relationship between reform, development, and stability must also be balanced. Moving forward requires both reform and becoming a responsible economic power."

(Former Governor Zhou Xiaochuan of the People's Bank of China [translation]) ${ }^{28}$

\section{SOVEREIGNTY THROUGH MONETARY INDEPENDENCE AND CONFLICT AVOIDANCE}

Stability on the inside requires stability on the outside. Contrary to popularly held belief in the West, when one analyzes the history of the Chinese nation, one discovers that it rarely resorted to actively starting an all-out total war with the outside non-Chinese world. This conflict avoidance is deeply embedded in Chinese culture. ${ }^{29}$ Their preferred method of conflict resolution traditionally used to be agreeableness, diplomacy, and trade. Every time China opened up to the outside world, it did so through trade envoys. And, every time a competing nation came to the realization that they are losing the trade game, they resorted to waging war on China or worse, since that was their only recourse promising victory. Chinese people learned their historical lesson from many conflicts such as the Opium wars, Japanese invasion, Sino-French war, or Soviet invasion. China's government is therefore doing everything in its power to not show any exploitable weakness anymore and to transform any problem into a trade

26 Id., pp. 211-228.

27 The Fourteenth Five-Year Plan for the National Economic and Social Development of the People's Republic of China and the Outline of Long-term Goals for 2035.

28 President Zhou Xiaochuan Accepts an Exclusive Interview with Caixin Weekly. In: The People's Bank of China [online]. 13.2.2016 [cit. 2021-03-27]. Available at: http://www.pbc.gov.cn/goutongjiaoliu /113456/113469/3016856/index.html.

29 TOMÁŠEK, M. Právní systémy Dálného východu. I. Praha: Karolinum, 2016, pp. 45-46. 
problem and address it accordingly. The fundamental issue with using trade as a method of conflict resolution or prevention is that trade requires an established trusted relationship between the two parties and inherently makes the two parties reliant on one another in a symbiotic relationship.

Governments, through their national banks, have been known to engage in the international market through artificial monetary interventions and other tools at their disposal. Some conventional such as devaluating their currencies, setting interest rates, or unconventional ones such as 21 st-century style quantitative easing policies, to help their own economies to facilitate growth or avert significant losses, often at a cost to the other economies or other parameters. ${ }^{30}$

When the Digital Yuan project is fully realized, it could become freer of these impacts and could also lead to completely circumventing global economic sanctions imposed on China, rendering them at least partially irrelevant.

On top of the problems outlined above, to enable trade, one needs to cover transaction costs in the form of large-scale infrastructure, logistics, and legal framework that needs significant investment and efforts in the beginning and throughout the relationship to maintain it. China is often happy to invest in new large scale infrastructure projects, even on foreign soil, provided the long-term trade prospects outweigh the cost of initial investments, as can be evidenced by large scale undertakings in the form of trade ports, roads, and railways built across Asia and Africa and rest of the world. ${ }^{31}$

This can be branded both as an altruistic foreign aid or checkbook diplomacy depending on one's view, but usually, the Chinese position voiced by Chinese media is that this is a form of trade between two equal parties, not free gifts. ${ }^{32}$ The Digital Yuan fits perfectly into this policy as China could potentially be "gifting" both the infrastructure for the deployment of the Digital Yuan and Digital Yuan itself in the form of larger economy-boosting "red envelopes". This topic will be further discussed below in paragraphs dedicated to the exportability potential of the digital RMB.

\section{THE US-CHINA TRADE WAR, THE FIGHT FOR THE WORLD'S RESERVE CURRENCY AND SOFT-POWER}

One of the more significant geopolitical conflicts successfully transformed into a trade conflict is the so-called "US-China Trade War", and as long as it remains a trade war, China will happily compete because they are confident in their ability to play the trade game.

30 JOYCE, M. et al. Quantitative Easing and Unconventional Monetary Policy - an Introduction. The Economic Journal. Vol. 122, No. 64, F271-288. p. F274. Available at: https://personal.lse.ac.uk/vayanos/Papers /QEUMCI_EJ12.pdf.

31 See Chapter 13 Section 2 of The Fourteenth Five-Year Plan for the National Economic and Social Development of the People's Republic of China and the Outline of Long-term Goals for 2035.

32 Commentary: the myth about China's "chequebook diplomacy". In: Xinhua News Agency [online]. 12.5.2017 [cit. 2021-03-27]. Available at: http://www.xinhuanet.com/english/2017-05/12/c_136277532 .htm. 
But the trade war is not necessarily just between the US and China, but also between the users of RMB and users of USD. More than 65 countries are tying their exchange rates to USD, and seven countries even use USD as their currency. ${ }^{33}$

Being the operator of the world's reserve currency brings many benefits. For example, monetary decisions are more impactful since they have influence beyond one's own country's borders. Another perk is the ability to borrow at lower costs. Finally, the data generated by using target currency can be gathered and analyzed to make better policy decisions. The more users use the currency means more and better data, which translates to more knowledge and, ultimately, power. Currently, these perks are utilized by the US government to a varying degree of competence. China would like to take some of that power for itself and provide a serious alternative. The unquestioned supremacy of the US dollar and the power that it gives to the Federal Reserve System (FED) is a longsought-after asset.

The Chinese government has been making consistent attempts to slowly erode the USD exclusivity and bring about more pluralism in financial geo-politics. ${ }^{34}$ Either through pushing for reforms to use Special Drawing Rights (SDR) rather than USD as the reserve currency or proposals to redesign the SDR system itself towards a more balanced basket by participating with the Chinese Yuan to affect the percentage share of USD. ${ }^{35}$ For the period of 2016-2020, the IMF reported a change in its SDR basket allocation. Presently we are at $41.73 \%$ share of USD, $30.93 \%$ share of EUR, and $10.92 \%$ share of RMB, with JPY and GBP taking up the rest. ${ }^{36}$

Beyond the direct macroeconomic advantages, there are more subtle advantages that the global adoption of the Chinese Digital Yuan would bring. Simply because of its market network effect, ${ }^{37}$ more business and trade opportunities would come to (or trade with) China. This would align foreign economies more closely with their internal market, establishing long-term dependency and economic commitment, which can be leveraged and exerted as a form of soft power to attain other non-economic goals, as we have seen the Chinese authorities regularly do - for example, refusing to grant or sudden suspension of market access when not complying with other legislation. This is, at least at some level, no different to the EU accepting trade deals on the condition of environmentally friendly policies and commitments towards enforcing international intellectual property law protecting European exporters' trademarks, or the USA ac-

33 ATKINS, T. Countries That Use the US Dollar. In: Investopedia [online]. 7.4.2020 [cit. 2021-03-27]. Available at: https://www.investopedia.com/articles/forex/040915/countries-use-us-dollar.asp.

34 BRYANSKI, G. China Backs Talks on Dollar as Reserve - Russian source. In: Reuters [online]. 19.3.2009 [cit. 2021-03-28]. Available at: https://www.reuters.com/article/wtUSInvestingNew s/idUSLJ93633020090319.

35 Factsheet: Special Drawing Rights. In: International Monetary Fund [online]. 18.2.2021 [cit. 28. 3.2021]. Available at: https://www.imf.org/en/About/Factsheets/Sheets/2016/08/01/14/51/Special-Drawing-Right -SDR.

36 Currency Composition of Oficial Foreign Exchanges Reserves (COFER). In: International Monetary Fund [online]. 23.12.2020 [cit. 2021-03-28]. Available at: https://data.imf.org/regular.aspx?key=41175.

37 Network effect (or alternatively network externality) is an economic phenomenon, where each new user increases the overall value of the product for the current users and subsequently makes it more attractive for new users, who then propagate this effect. 
cepting trade deals on the condition of reciprocated market access and liberalization of standards.

\section{FOREIGN HORIZONS AND BEYOND}

Another very clear goal is to realize the exportability potential of the digital Yuan. China is trying to build and has been actively trying to build for more than two decades, together with other countries, what we could call a new form of "Asia". According to foreign policy experts like Parag Khanna, Asia is aspiring to be much more than just a continent, but an alliance rivaling and eventually surpassing EU or NAFTA. ${ }^{38}$ China is at the core of institutions like ASEAN $+3,{ }^{39}$ Regional Comprehensive Economic Partnership, and most importantly, the Asian Infrastructure Investment Bank (AIIB). Especially the AIIB, which is being considered as a prime rival to IMF and World Bank, ${ }^{40}$ and its activity illustrates the value of economic diplomacy.

Europe, or the EU for this matter, is deeply connected on a historical, cultural, economic, political, and administrative level. The same can be said about the United States. However, for China all of these connecting attributes, especially the administrative, are unachievable (at least for the foreseeable future), according to Khanna. ${ }^{41}$ As Khanna says: "There is no supranational Asian parliament, central bank, or military - no 'Asian Union'. "42 However, there might be an "Asian Euro" in the form of the Digital Yuan. It may not seem like it now, but there is concrete evidence that China is actively trying to do so. In 2019, the Bank of China and Hong Kong Monetary Authority conducted a pilot project named Project Inthanon-LionRock. ${ }^{43}$ Now the Hong Kong Monetary Authority (HKMA), the Bank of Thailand, the Central Bank of the United Arab Emirates, and the Digital Currency Institute of the People's Bank of China jointly announced they are joining together and expanding on the project. ${ }^{44}$ This can be considered as the first broadening of the digital RMB outside China's borders. ${ }^{45}$ China's ambitions are not limited to Asia but other continents as well. More and more institutions could join

38 See for example KHANNA, P. The Future is Asian. London: Weidenfeld \& Nicolson, 2019.

39 The Association of Southeast Asian Nations, an economic union of 10 countries (Brunei, Cambodia, Indonesia, Laos, Malaysia, Myanmar, Philippines, Singapore, Thailand, and Vietnam). ASEAN+3 includes China, South Korea, and Japan.

40 See for example SHARAR, H. - JONES, L. China challenges global governance? Chinese international development finance and the AIIB. International Affairs. 2018, Vol. 94, No. 3, pp. 573-593.

41 KHANNA, c. d., p. 13.

42 Id.

43 The Outcomes and Findings of Project Inthanon-LionRock and the Next Steps. In: Hong Kong Monetary Autority: Press Releases [online]. 22.1.2020 [cit. 2021-03-10]. Available at: https://www.hkma.gov.hk /eng/news-and-media/press-releases/2020/01/20200122-4/.

44 Joint statement on the Multiple Central Bank Digital Currency (m-CBDC) Bridge Project. In: Hong Kong Monetary Autority: Press Releases [online]. 23.2.2021 [cit. 2021-03-10]. Available at: https://www.hkma .gov.hk/eng/news-and-media/press-releases/2021/02/20210223-3/\#1.

45 Technically speaking, even the Project Inthanon-LionRock with Hong Kong from 2019 to 2020 could be considered an "outside of borders" expansion. However, given the nature of Hong Kong as the Special Administrative Region, the expansion to countries such as Thailand or UAE can be considered as a true international expansion. 
in the future. The technical nature of the digital RMB and digital currencies in general certainly make it conducive for broader international usage.

\title{
REAL-TIME BIG DATA MONITORING OF INTERNAL AND EXTERNAL FLOW OF CAPITAL
}

\begin{abstract}
"There are many uncertain factors in the current global financial market, leading to divergent opinions and more disputes. At this time, everyone hopes that a certain prophet or authoritative statement can turn uncertainty into certainty. But uncertainty exists objectively in the market, and it cannot be eliminated by mere verbal reassurance. The central bank is neither a god nor a magician, and it is impossible to erase the uncertainty problem. Therefore, the central bank sometimes says: 'I' $m$ sorry, we have to wait for the input of new data.', (Former Governor Zhou Xiaochuan of the People's Bank of China [translation]) ${ }^{46}$
\end{abstract}

The policymakers in their attempts to govern the ungovernable have often struggled with a single parameter - time. When a problem occurs, it takes a while before it is recognized, identified, action requested, solution thought of, and implemented. By then, it might have been too late because months and years have already passed. The policymakers are always at the far last place of the cycle of innovation and events.

Traditionally, central bankers have been hard-pressed to address problems to which they have no meaningful data and limited simulation capabilities to optimize the degree of utilization of their blunt instruments. And the instruments themselves have delayed effects as well; therefore, it takes time before their influence is properly propagated and realized within the economy. The Digital Yuan is a powerful gamechanger. Made precisely to monitor the flow of money and behavior of the market in real-time. On top of that, it includes various meta-data relating to goods and services or natural or legal persons involved. The all-encompassing Digital Yuan economy will provide Chinese central bankers with an almost omniscient datamining evaluation tool.

More users, domestic and foreign, who will use the Digital Yuan will provide more data. Given the advances in statistical modeling, only a relatively small percentage of total users from target demographics need to use the Digital Yuan, as one can infer the behavior of the whole via statistics. Better yet, all of this input data can be stored and simulated in a dynamic data model. Policymakers may engage in predictive simulations. Then based on their findings, they can use the strategy that yielded the best results in the simulated world and apply it in the real world. China is no stranger to AI and is a leader in industry investments. ${ }^{47}$ Also, the real-time nature of the Digital Yuan allows for near-instant propagation of effects directly to end-users.

The ultimate end goal may be that this process of evaluation and instrument dissemination will be automated and engaged without requiring constant human supervision,

46 President Zhou Xiaochuan Accepts an Exclusive Interview with Caixin Weekly.

47 LI, D. - TONG, W. T. - XIAO, Y. Is China Emerging as the Global Leader in AI. Harvard Business Review [online]. 18.2.2021 [cit. 2021-03-31]. Available at: https://hbr.org/2021/02/is-china-emerging-as-the-global -leader-in-ai. 
operating consistently and tirelessly on the fly, bringing about a dynamic autonomous smart economy.

\title{
LAW ENFORCEMENT - A NEXT-GENERATION POLICING TOOL
}

\begin{abstract}
"From the perspective of the central bank, the future digital currency must do its utmost to protect privacy, but security and order are also important. In case of illegal or criminal problems, it is necessary to retain the necessary verification methods, that is, to protect and to find a balance between privacy and combating illegal and criminal behavior. The mastery of the balance between these two motives also makes technical choices different."

(Former Governor Zhou Xiaochuan of the People's Bank of China [translation]) ${ }^{48}$
\end{abstract}

Offenses such as corruption, bribery, embezzlement, terrorism financing, and money laundering are difficult to uncover due to their sophisticated obfuscation by perpetrators. The Chinese government is expecting that the Digital Yuan will go a long way, especially with other data-heavy law enforcement tools such as CCTV, digital communication monitoring, to ultimately crack down on this type of criminal activity.

No civilization or society can function without common rules that are enforced when not followed. The only reason China was able to survive its rapid growth is through rigorous self-policing and overzealous discipline, no matter the cost. Respect towards law enforcement in China is quite high, and that is reflected in their criminal and civil procedure laws. For the sake of briefness, here is a glimpse into the powers the law enforcement is endowed with and the severity of the consequences (translated).

Upon failure to enforce debts through civil action, the debtor becomes what the Chinese call "old debtor". This gives Chinese courts more options for punishment measures, for example:49

"- restrict exit from China

- record the failure in the credit system ${ }^{50}$ - publish information on the failure in media ${ }^{51}$ - other measures".

What qualifies as "other measures" is explained in Article 3 of Several Provisions of the Supreme People's Court on Restricting High Consumption of Judgment Debtors:

"Where the person subject to enforcement is a natural person, after measures of consumption restrictions are taken against him or her, he or she may not have the following high consumption and consumption not necessary for life or work:

(1) To take an airplane, take the soft berth of a train, or take the second-class berth or above as the means of transportation;

(2) To have high consumption activities at star hotels, night clubs, golf courses, etc.;

48 President Zhou Xiaochuan Accepts an Exclusive Interview with Caixin Weekly.

49 Article 255 of The Civil Procedure Law of the People's Republic of China.

50 This provision refers to the financial credit system, not the infamous social credit system.

51 Loss of reputation (Face) in a public manner is a serious punishment in Asian countries, including China. 
(3) To purchase real estate, or build, expand, or luxuriously furnish houses;

(4) To rent high-end office buildings, hotels, apartments, or other places for doing businesses;

(5) To purchase vehicles not necessary for business operations;

(6) To travel or take a vacation;

(7) To send his/her children to high-cost private schools;

(8) To purchase insurance and financial products by paying a high premium; and

(9) To take any seat in a G-High-Speed Electric Multiple Units (EMU trains) or to take a seat of the business class or a higher class in any other EMU train, or to have any other consumption not necessary for life or work."

To enforce these other measures, the Chinese government developed a series of blacklists that all provisioners of said services must check prior to accepting a contract with the contracting party. When an "old debtor" attempts to buy forbidden goods or services, the law enforcement is immediately notified. The Digital Yuan should be considered a technical extension of this pallet of advanced tools already in use that will accompany law enforcement capabilities in dealing with civil, criminal, and administrative offenses.

The adoption of the Digital Yuan raises substantial privacy concerns. Moreover, any data-heavy tool of such scale might bring about a more likely occurrence of unlawful use of data for illicit purposes. Such arrangement requires a higher degree of trust, transparency, and accountability of law enforcement to justify the extensive surveillance and systemic intrusion of privacy.

\section{REGULATING FINTECH INDUSTRY}

In order to use any online services, which are indispensable to day-to-day functioning, there is an increasing need for online payment methods. In China, there are two alternatives, Alipay (owned by Ant Financial, which is owned by Alibaba Group) and WeChat Pay (part of the WeChat app, owned by Tencent). ${ }^{52}$ They both engage in the market and are virtually inseparable. Every merchant, online or offline, accepts both. Cash in China was almost entirely replaced by QR codes during the last five years. ${ }^{53}$

Fintech companies have been the driving force behind a lot of the growth China presently enjoys, but such accumulation of wealth led to absorption and monopolization of the market, which begins to produce signs of anti-competitive behavior and is ultimately harmful to the long-term health of the economy. Stakeholders and executives of these companies are often perceived as persons with high public authority and influence and,

52 The two companies effectively form a duopoly with around 90-95\% market share (Alipay has a slightly larger market share.). See e.g., Alipay Maintains Dominance in China Over Tencent's WeChat Pay and QQ Wallet. In: Fintech News Hong Kong [online]. 9.7.2020 [cit. 2021-03-31]. Available at: https:// fintechnews.hk/12618/mobilepayment/alipay-maintains-dominance-in-china-over-tencents-wechat-pay -and-qq-wallet/.

53 See e.g., WANG, S. Why China can't get enough of QR codes. In: CNN Business [online]. 8.9.2017 [cit. 2021-03-31]. Available at: https://money.cnn.com/2017/09/08/technology/china-qr-codes/index.htm. 
as such, are subject to attention both from the media and the Chinese government. ${ }^{54}$ Taking back control from the fintech industry and redirecting it to a carefully regulated banking industry and elegantly using the Digital Yuan is thus another very clear goal of the Chinese government.

There is, however, an argument in favor of retaining established privately owned market gatekeeper enterprises because since they are concerned with profit only, their decision-making is apolitical and neutral. Whereas a government-run gatekeeper, as a public entity, has vested interest not in profit but in political goals, which may be substantially different. The argument against private fintech operators of currency is that legally and factually, they are a private company, and there is always a possibility they can default and eventually go bankrupt, dragging the entire currency and savings of their users with them.

Finally, it is worth noting that fintech industry regulation is not limited only to transaction services. Notably, micro-loans and financial services have been put under tighter scrutiny. In November 2020, The People's Bank of China and Banking and Insurance Regulation Commission jointly released a draft of the Online Micro-loan Operations Provisional Administrative Measures, limiting online micro-loan balance and further restricting and regulating micro-loan companies. ${ }^{55}$

\section{PREVENTING THE THREAT OF OTHER CURRENCY ALTERNATIVES}

The Digital Yuan is itself a player within a greater market of currencies. The Digital Yuan has a lot to offer to the government, but very little new can be offered to end-users. We may expect a huge PR campaign by the Chinese government to sell their new currency to their population and across the borders, starting (but not ending) with the Winter Olympics in 2022 already mentioned in the introductory part of the paper above.

Those that will not adapt to the new digital currency willingly because of positive reinforcement incentives might eventually be forced through market forces, and ultimately, they will be forced through formal and informal policies and regulations. This was precisely shown in China's government attitude towards cryptocurrencies and fintech mentioned above.

Apart from traditional competition from the world's established currencies, what the Chinese government also fears are private, decentralized cryptocurrency alternatives, as was explained at the beginning of this paper. There are many reasons why this fear is well-founded, details of which authors wish to explore in a follow-up paper focusing on the costs and benefits of different currency options (private currencies, digital

54 PEACH, S. Why did Alibaba's Jack Ma disappear for three months? In: BBC News [online]. 20.3.2021 [cit. 2021-03-28]. Available at: https://www.bbc.com/news/technology-56448688.

55 China Unveils New Online Lending Regulations Restricting Cross-border Operation, Leverage Levels and Lending Amounts. In: China Banking News [online]. 3.11.2020 [cit. 2021-03-31]. Available at: https:// www.chinabankingnews.com/2020/11/03/china-unveils-new-online-lending-regulations-restricting-cross -border-operation-leverage-levels-and-lending-amounts/. 
currencies, cryptocurrencies, etc.). The bottom line is that the existence of alternative (crypto)currencies can undermine many of the goals of the Digital Yuan mentioned in this article.

\section{ONE CHINA - CIVILIZATION IS A "HUMAN RIGHT" FOR CHINESE CITIZENS}

The Digital Yuan is being deployed through big business platforms in areas that are economically developed, such as the Greater Bay Area, Beijing-Tianjin-Hebei cluster, and Yangtze River Delta. These areas are highly conducive to technology, as was mentioned before. If the roll-out of the new digital currency would be problematic to use, it would permanently damage the reputation and discourage a universal wide adoption across the country.

But the master plan also mentions some western and central regions where conditions permit. These preconditions are two-fold, as Liu Zhiqin from the Chongyang Institute for Financial Studies at Renmin University of China explains. ${ }^{56}$ One aspect is the technological infrastructure, internet connection, universal smartphone ownership. The other aspect is cultural; people need to get used to e-commerce, and they need to be educated on how to handle and execute such transactions. They need to understand and place their trust in the Digital Yuan.

There are remote areas in China, especially far inland, where high-speed trains are yet to be built, universal, affordable internet coverage have yet to be provided, modern public services and institutions have yet to be established. This is called the digital divide, and it is very prominent in China, with its size of 9.6 million square kilometers. There are millions of Chinese people who have not yet had the opportunity to experience modern life, but it is one of the major goals of the government to grow inland and bring them up to speed, technologically and culturally, because in turn, they will join to the greater Chinese internal market to fuel the economy. ${ }^{57}$

Bridging the gap between the coast and inland, between the urban and rural, has been difficult, but there are successful examples such as Yangtze River Midstream Megalopolis (composed of Wuhan, Changsha, Nanchang, and others), Chengyu Megalopolis (composed of Chongqing, Chengdu, and others), or Central Plain Megalopolis (Zhengzhou and surrounding cities), that although quite distant from the coast have become a breathtaking economic success and shining hubs of development for surrounding cities. This all is both an obstacle and a goal for the Digital Yuan to overcome and fulfill.

56 ZHIQIN, L. How has the digital yuan fared so far? In: CGTN [online]. 19.8.2020 [cit. 2021-03-31]. Available at: https://youtu.be/cKDw2BE8fJI?t=492.

57 China Focus: China seeks to bridge the digital divide for elderly. Xinhua News Agency [online]. 26.11. 2020 [cit. 2021-03-31]. Available at: http://www.xinhuanet.com/english/2020-11/26/c_139544553.htm. 


\section{INCREASING THE EFFICIENCY OF TAX COLLECTION}

Taxes are the foundation of the state because they serve to cover the vast public expenditures made by the government. China's budget balance in relation to a gross domestic product, as reported, has been taking a deep dive. For almost a decade, China has been running a deficit budget, and its national debt has been rapidly increasing..$^{58}$ The People's Republic of China has traditionally been a socialist republic, and greater public spending is an inherent part of the vast system that finances various policies and extensive public services. But in order to keep the system sustainable, it has to be accompanied by matching sufficient revenues from taxes as well. Tax avoidance is therefore also a concern in China, and digital payments and wire transfers have helped to tackle this problem. Capturing the growth in proper channels and effectively taxing it through e-government innovation has thus also been a significant motivation behind the digital currency.

\section{CONCLUSION}

China has always been at the forefront of financial reform and innovation, dating back as far as the 7th century with the introduction of the first paper banknotes during the Tang Dynasty. Today, in the second decade of the 21st century, China is once again trying to revolutionize payment. The Chinese government may not be the only government trying to implement this new form of digital currency, but it is by far the most advanced, at least for now.

There are clear goals, which the Digital Yuan aims to achieve. Such as it being a multi-purpose weapon aimed both at domestic (regulating fintech companies and providing another tool to monitor and control citizens) and foreign enemies (influencing global trade and becoming more resilient against external influences). It is also clearly a political tool of diplomacy, enabling more control over foreign companies and individuals that are captivated to tap into the vast Chinese internal market, as well as providing yet another tool China can use to (in)directly strengthen their existing position in foreign markets.

Is the Digital Yuan and the way it is being implemented in China a suitable inspiration that can be learned from or even applied universally? The answer would be easier to construct should the subject of the article be cryptocurrencies. Digital currencies are a distinct phenomena separate from cryptocurrencies and other types of crypto commodities, which might be further explored by the authors at a later date.

58 China: National debt from 2015 to 2025. In: Statista [online]. [cit. 2021-03-30]. Available at: https://www .statista.com/statistics/531423/national-debt-of-china/. 
If the way the Chinese have dealt with cryptocurrencies (as described earlier in this paper) in comparison with the path taken by the $\mathrm{EU}^{59}$ and $\mathrm{USA}^{60}$ so far is any indication, the scope of the debate will be a venue for many conflicting values that will shape the design decisions of each country in implementation of their version of digital currency.

The purpose of this article was to introduce the Digital Yuan in a broad context, describing the project and its China-specific legal and cultural aspects that accompany it. The authors of this paper are hopeful that this will open the debate about the Digital Yuan in relation to other CBDS and virtual currencies, may it be legal, economical, or sociological.

\author{
Mgr. Martin Samek \\ Právnická fakulta Univerzity Karlovy \\ samek@prf.cuni.cz \\ Martin Vlasta \\ CIO, advokátní kancelář Císař, Češka, Smutný \\ vlasta@akccs.cz
}

59 In the EU, it is the proposed "MiCA" regulation (Regulation of the European Parliament and of the Council on Markets in Crypto-assets), which harmonizes EU legislation focusing on cryptocurrency issuers, cryptocurrency service providers and consumers. Unlike in China, the MiCA is not prohibiting cryptocurrency companies to exist, but it is setting up transparent rules for companies who wants to enter the market as well as protecting consumers in crypto-currency market.

60 In the USA, the regulation differs state by state. On the federal level, despite crypto currencies being on the radar of federal agencies like the Securities and Exchange Commission and Federal Trade Commission, a cautious approach has been applied so far with fears of possible over-regulation prohibiting natural evolution of this new technology. 